Article

\title{
Evaluation of Life-Cycle Assessment Analysis: Application to Restoration Projects and New Construction in Alpine Climate, Japan
}

\author{
Yohei Endo ${ }^{1, *(\mathbb{D})}$ and Hideki Takamura ${ }^{2}$ \\ 1 Department of Architecture, Shinshu University, Nagano 380-8553, Japan \\ 2 Faculty of Engineering, Shinshu University, Nagano 380-8553, Japan; takam@shinshu-u.ac.jp \\ * Correspondence: endii@shinshu-u.ac.jp; Tel.: +81-26-269-5345
}

Citation: Endo, Y.; Takamura, H. Evaluation of Life-Cycle Assessment Analysis: Application to Restoration Projects and New Construction in Alpine Climate, Japan. Sustainability 2021, 13, 3608. https://doi.org/ $10.3390 /$ su13073608

Academic Editor:

Oriol Pons-Valladares

Received: 13 February 2021

Accepted: 16 March 2021

Published: 24 March 2021

Publisher's Note: MDPI stays neutral with regard to jurisdictional claims in published maps and institutional affiliations.

Copyright: (c) 2021 by the authors. Licensee MDPI, Basel, Switzerland. This article is an open access article distributed under the terms and conditions of the Creative Commons Attribution (CC BY) license (https:/ / creativecommons.org/licenses/by/ $4.0 /)$.

\begin{abstract}
The present paper discusses the applications of life-cycle assessment (LCA) to construction works in Japan. LCA has been frequently used to assess the environmental impacts of new construction. Nonetheless, the applications of LCA to restoration have not been fully confirmed to date. It is said that historical buildings may contribute to sustainable development. Nonetheless, as for heritage buildings, since the protection of cultural value is usually prioritised, their environmental impacts may not be sufficiently explored. To this aim, this paper evaluated the environmental impacts of the restoration of heritage buildings. This paper consisted of two tasks. First, the restoration projects of heritage buildings in Japan were introduced. The restoration of two heritage houses was discussed, referring to heritage protection legislation in Japan. Second, LCA was performed on the restoration of heritage houses and the construction of contemporary houses. Environmental impacts were compared between the restoration and new construction with regard to greenhouse gas emissions and operational energy use. A focus was given to the amount of materials used. Restoration consumes a limited amount of materials compared to new construction, although the energy use of heritage buildings is considerable. The environmental impacts of restoration were quantified so that they were compared with those of new construction. The comparison indicated issues applying LCA to heritage buildings.
\end{abstract}

Keywords: life-cycle assessment; restoration; heritage architecture; timber-frame structure; residential building

\section{Introduction}

The increase in the world's population in recent decades has had significant environmental impacts [1]. It is an urgent task to protect the Earth, but at the same time, the sustainable development of the economy and society has to be ensured [2]. The word "sustainability" started to appear with frequency since 2000 [3]. Sustainability is defined as the state of the global system in which the environmental, social and economic requirements of today's generations are satisfied without undermining the ability of future generations to do so [4]. The building industry is responsible for high levels of energy consumption and $\mathrm{CO}_{2}$ emissions [5-9]. The conservation of historic buildings may be favourable to sustainability in terms of natural and man-made resources compared to new construction [10-12]. The continuing use of historic buildings may contribute to a reduction in environmental impacts derived from construction activities [13,14]. In addition, well-executed conservation practice may reduce life-cycle $\mathrm{CO}_{2}\left(\mathrm{LCCO}_{2}\right)$ emissions as energy efficiency is improved [15-18]. Nonetheless, when conservation practice focuses on structural strengthening as well as the protection of cultural value, environmental impacts may not be paid sufficient attention to [19-22]. When projects aim to improve structural safety and control environmental impacts at the same time, they may require additional costs [23]. 
Life-cycle assessment (LCA) is often used to measure the environmental impacts of construction works $[5,24-26]$. LCA contributes to the minimisation of the environmental impacts of the entire life cycle of buildings: the manufacturing of materials, transport, construction, maintenance and final disposal (so-called cradle-to-grave process) [27]. The International Organization for Standardization (ISO) presented LCA principles and frameworks to measure and control such impacts [4]. National and international standards refer to the publications of the ISO [28-30]. LCA can be a useful tool for the conservation of historic buildings [31-33]. LCA can contribute to the reduction in $\mathrm{LCCO}_{2}$ emissions of historic buildings by prolonging the service lives of used materials [34], proposing energy-efficient seismic strengthening [35] and improving the energy efficiency of buildings [36-39]. However, the reliable application of LCA to conservation practice requires further investigation and practice [40-42]. Results may be influenced by the considered lifespan, databases, system boundaries and reference study period [43-46]. The choice of indicators must be based on the well-defined objectives of LCA [47]. The LCA of historic buildings can be challenging as databases do not usually include traditional materials $[48,49]$. The evaluation of results may not be straightforward when subjective judgements (e.g., emotional and memorial values) are taken into account [43]. To increase the credibility of LCA results, sensitivity analysis is advisable [50-52]. The estimation of the environmental performance of historic buildings may be improved by taking into account the influences of temporal parameters including climate changes and toxicity impacts [53]. Due to the stochastic characteristics of historic buildings, probabilistic approaches may be necessary $[46,54,55]$. As a matter of fact, in the framework of the 2030 Agenda for Sustainable Development Goals (SDGs), the International Council on Monuments and Sites (ICOMOS) explores approaches that permit the enhancement of the sustainability of urban areas by means of heritage built environments [56]. The SDGs are internationally recognised, but limited research progress has been made in terms of the environmental performance of buildings for the achievement of SDGs [57]. In addition, studies have been focused on contemporary buildings [58,59].

This paper applies an LCA methodology to the restoration of heritage houses and the construction of contemporary houses. Buildings in Japan are considered as case studies. The applied LCA compares environmental performance between restoration and new construction. The restoration of heritage buildings needs to satisfy the protection of cultural value, as it may require substantial environmental impacts. For this reason, it is essential to properly calibrate the environmental impacts of restoration projects. The aim of this paper is to indicate the difficulties of LCA application to heritage buildings and the applicability of an existing LCA methodology by comparing restoration projects and new construction. The comparison focuses on the environmental impacts of the amount of construction materials and of the operational energy use. The applicability of LCA is examined in terms of the quantification of the environmental performance of the restoration of heritage buildings.

\section{Research Methodologies}

\subsection{LCA Methodology}

The methodology of the Architectural Institute of Japan (AIJ) [30] was adopted. The building life-cycle phase consists of construction, operation, maintenance, replacement and disposal as system boundaries. Figure 1 shows the system boundaries considered in the methodology. The presented display is based on the European standard [29]. The blue italic words are the boundaries considered in the methodology of the AIJ. It is noted that the construction phase is composed of the product and the construction process stage. 
Construction

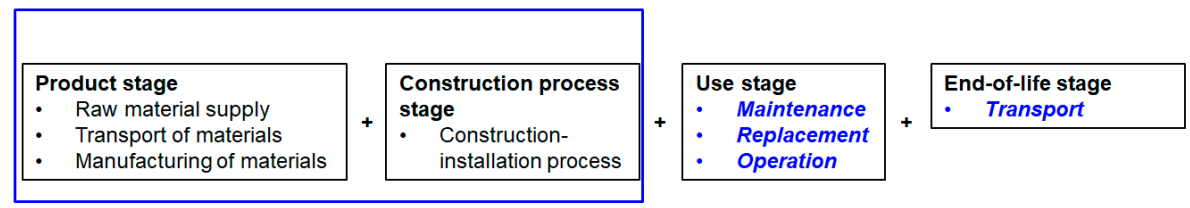

Figure 1. System boundaries considered in the methodology of the Architectural Institute of Japan (AIJ).

The product stage is calculated according to the structural components. They are foundations, structural frames, floors, roofs, walls and furnishings. The furnishings are non-load-bearing interior components. The methodology considers $\mathrm{CO}_{2}, \mathrm{NO}_{\mathrm{x}}, \mathrm{SO}$, chlorofluorocarbon (CFC) and primary energy consumption as the indicators. Equation (1)

$$
G W P_{m, l}=V_{m, l} \times \gamma_{m, l} \times C_{m, l}\left(\mathrm{~kg}-\mathrm{CO}_{2} \mathrm{eq}\right)
$$

where:

$G W P_{m, l}$ is the global warming potential (GWP) of a material, $m$ for the structural component $l$ of the building $(\mathrm{m}=1,2,3, \ldots, \mathrm{N})$

$V_{m, l}$ is the volume of a material, $m$ for the structural component $l(\mathrm{~m}=1,2,3, \ldots, \mathrm{N})$

$\gamma_{m, l}$ is the density of the material, $m$ for the structural component $l(\mathrm{~m}=1,2,3, \ldots, \mathrm{N})$

$C_{m, l}$ is the unit GWP of the material per square meters, $m$ for the structural component $l$ $(\mathrm{m}=1,2,3, \ldots, \mathrm{N})$

Calculates the GWP of a material used for a structural component. The resultant GWP emissions are obtained by summing the GWP of each structural component. The GWP of the construction process stage is considered proportional to that of the product stage [30]. It is equal to $24.7 \%$ of the product stage for timber-frame buildings. The maintenance is considered to be performed every year. Its yearly GWP is set at $1 \%$ of the construction phase. The maintenance is performed on walls, roofs and furnishings. As for the replacement, the structural components are assigned their own service lives. According to them, they are replaced. As for the disposal, only the transport of the materials is considered as waste management facilities are considerably different in each region in Japan [30]. Typical waste collection vehicles are considered. Transport distance is considered $30 \mathrm{~km}$.

This paper considered the database of the Japanese standard [30]. It is comprehensive and covers materials of a wide range of building types. It includes electricity and energy sources such as gas and petrol as well. Inter-industry relationships are taken advantage of [60]. They are presented as input-output matrices. The statistical data of greenhouse gas emissions and energy use are reported periodically [61]. The database correlates the input-output matrices with the indicators, referring to the statistical data report.

\subsection{Energy Use Calculation Method}

Operational energy use is estimated according to the calculation method of the Japanese standard [62]. Cooling/heating, ventilation, water heating and lighting are considered. The method is widely used in Japan. The calculation is conducted using an online tool [63]. The method calculates the final energy consumption based on the average heat transfer coefficient (HTC), $\mathrm{U}_{\mathrm{A}}$, the average solar heat gain coefficient (SHGC), $\eta$, the floor area of a building, the area of the building skins and building-related domestic appliances. The $\mathrm{U}_{\mathrm{A}}$ value is calculated as an average value of the HTCs of the entire building skins. The HTCs are calculated based on the thermal conductivities of used materials and the thickness of structural components. The $\eta$ value is an average value of the SHGCs of the building skins which receive sunlight directly. Two $\eta$ values are used: namely SHGC for cooling $\left(\eta_{\mathrm{C}}\right)$ and heating $\left(\eta_{\mathrm{H}}\right)$. The standard defines that the cooling is required when the average temperature of a day is higher than 23 degrees. The heating is required when the average temperature is lower than 15 degrees. 


\subsection{LCA Application}

LCA was applied to two heritage houses and a contemporary house, using the LCA methodology presented in Section 2.1. Case studies are introduced in Section 3. The examined heritage houses were selected since they show representative characteristics as Japanese heritage buildings in terms of structural configurations, materials, cultural value and restoration approaches. On the other hand, the contemporary house was chosen so that it could be compared with the heritage houses.

The methodology considers that the life-cycle phase is composed of construction, operation, maintenance, replacement and disposal as discussed in Section 2.1 (see Figure 1). In this study, the reference study period was set at 45 years. The service life of typical houses in Japan is 45 years [64]. As for heritage buildings, extensive restoration, which may involve the dismantling of an entire building, is usually performed every 100 years [65]. Hence, the service life of the heritage buildings was considered 100 years while that of the contemporary house 45 years. The restoration was considered to be performed at the beginning of the reference study period. Table 1 presents the considered service lives of the buildings and of structural components. The structural components presented in the table are discussed in Section 3. The reference study period was chosen as it was unlikely that the same contemporary house will be built in 45 years considering technological development in recent years.

Table 1. Service lives of the studied buildings and of structural components.

\begin{tabular}{ccccc}
\hline (Years) & Structural Components & SA-RES & SO-RES & Contemporary House \\
\hline \multirow{2}{*}{ building } & & 100 & 100 & 45 \\
\hline \multirow{3}{*}{ roof } & ceramic tile roofs & 100 & - & - \\
\cline { 2 - 5 } & timber-plank roofs & - & 30 & - \\
\cline { 2 - 5 } & galvalume roofs & - & - & 25 \\
\hline \multirow{3}{*}{ wall } & lime plaster walls & 100 & 100 & - \\
\cline { 2 - 5 } & earth covering walls & 100 & 100 & - \\
\cline { 2 - 5 } & cement siding & - & - & 45 \\
\hline \multirow{3}{*}{ furnishing } & lime plasterboards & - & - & 45 \\
\cline { 2 - 5 } & interior timber boards & - & - & 45 \\
\cline { 2 - 5 } & tatamis & 15 & 15 & - \\
\hline
\end{tabular}

Three sensitivity analyses were performed. The first one examined the influences of material choices in the database. The second one was conducted to examine the environmental impacts of operational energy use by considering different technical systems. The third one examined the influences of the reference study period. In this paper, the units of the indicators were divided by the gross floor area of the buildings (e.g., $\mathrm{kg}-\mathrm{CO}_{2} \mathrm{eq} / \mathrm{m}^{2}$ ). This treatment made the results comparable among the buildings of different floor areas. 


\section{Description of the Case Study Heritage Buildings}

\subsection{Description of the Heritage Houses}

Case studies are positioned in Nagano prefecture, Japan. The prefecture is located in the central upland region. The average altitude of the prefecture is $600 \mathrm{~m}$. The region belongs to alpine climate which is characterised by low humidity, low temperature and substantial snowfall in winter [66]. The average highest temperature is 24.7 degrees Celsius while the lowest -3.2 degrees Celsius. The yearly snowfall is $30 \mathrm{~cm}$ on average.

Two heritage residential buildings were considered. Comprehensive descriptions of the heritage buildings including the restoration projects are found in the restoration reports $[67,68]$. The structures are built of timber frames. The first case study, Sanayama residence (SA-RES) was built in 1766 [69,70]. It is a two-storey building. It was used as a brokerage company and a lodge as well as a residence. It has been inscribed as an important cultural property as a representative example of traditional lodge-type structures since 1973. The dimension of the ground floor is $10.9 \times 7.8 \mathrm{~m}^{2}$ in plan (Figure 2a). The gross floor area is $237.4 \mathrm{~m}^{2}$. The height of the ground floor is $4.0 \mathrm{~m}$ while that of the first floor $2.0 \mathrm{~m}$ (Figure $2 \mathrm{~b}, \mathrm{c}$ ). The ground floor consists of four zones: a living quarter, guest rooms, a reception, an annex and an aisle. Part of the first floor is on the reception while the rest on the aisle and the annex (Figure 2b). The southern part room is the reception. The rooms in the central part are the living quarter and are served as dining rooms, sitting rooms and bedrooms. The rooms are separated by removable partitions. They are made of timber and usually covered with paper. One large space is created by removing the partitions. It is noted that it was typical for rooms to serve multiple purposes in traditional houses [70,71]. The northern part rooms are the guest rooms. The annex is used as a storeroom. The aisle is served as a kitchen and also as a corridor (Figure 2c). The floors of the aisle are at the ground level, as it is easily accessible from outside [72]. The first floor is used as guest rooms and storerooms.

The structural frames are composed of cedar, pine and cypress. The floors of the reception are covered with timber planks while those of the living quarter and of the guest rooms with timber boards and tatamis. The timber boards are made of pine. The tatamis are mats made from wooden chips (traditionally from rice straws). Their surfaces are covered with rush straws. The floors of the aisle are covered with earth. Walls are composed of bamboo meshes covered with earth. They are finished with lime plaster (Figure 2d,e). Such walls are typically seen in traditional buildings. The roofs are composed of timber planks and ceramic tiles. The timber planks of the roofs are made of pine.

The second case study, Sonehara residence (SO-RES) was built during the 17th century although the exact construction date is not known [68,73]. It is a single storey. It was used as a manor farmhouse. It has been inscribed since 1973 as an important cultural property as one of the oldest existing buildings which demonstrate indigenous construction techniques in the region. The dimension is $19.6 \times 15.9 \mathrm{~m}^{2}$ in plan (Figure 3a). The gross floor area is $276.5 \mathrm{~m}^{2}$. The height of the ground floor is $4.0 \mathrm{~m}$ (Figure $3 \mathrm{~b}$ ). The building consists of a living quarter, guest rooms, an aisle and a stable. The living quarter and the guest rooms are located on the north side while the stable on the south side (see Figure 3a). The rooms on the west side are used as the living quarter while those on the east side the guest rooms. Like SA-RES, rooms are separated by removal partitions (Figure 3e). Since the region belongs to cold alpine climate, it used to be typical for a farmhouse to use part of a house as a stable for livestock [68]. In addition, wind frequently blows in the north-south direction in the region. As a result, the south elevation has few openings (Figure 3c,d). In fact, the entrance is located in the east elevation. 
(a)

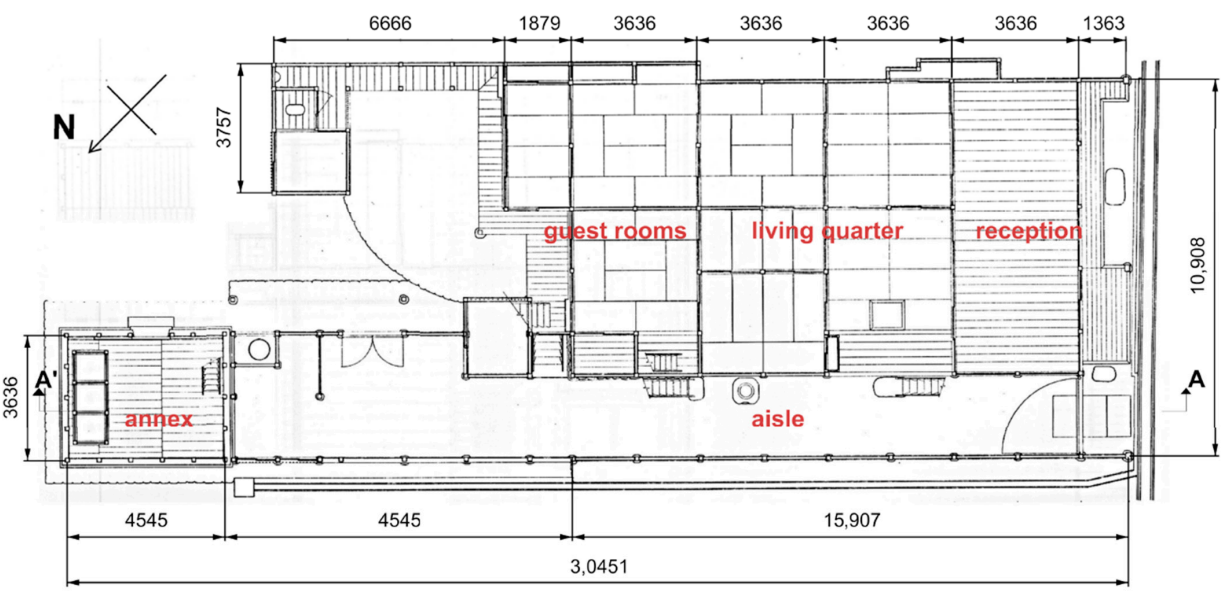

(b)

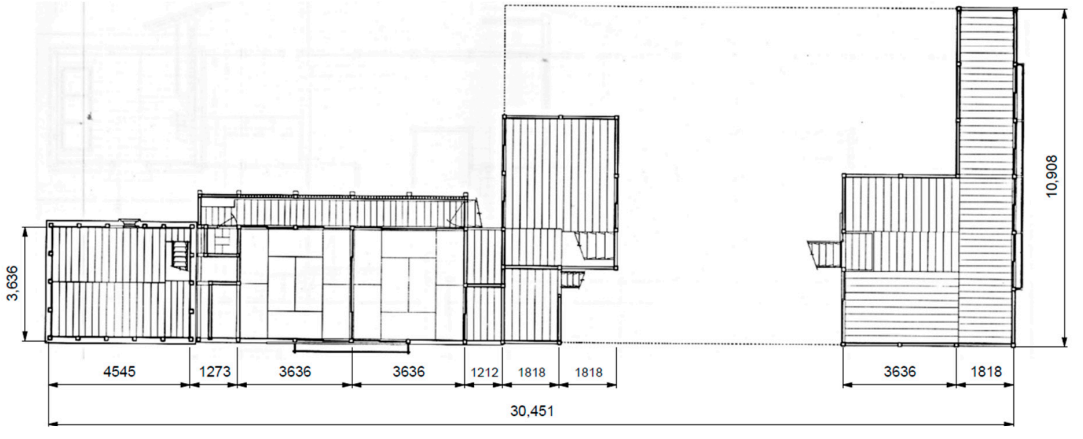

(c)
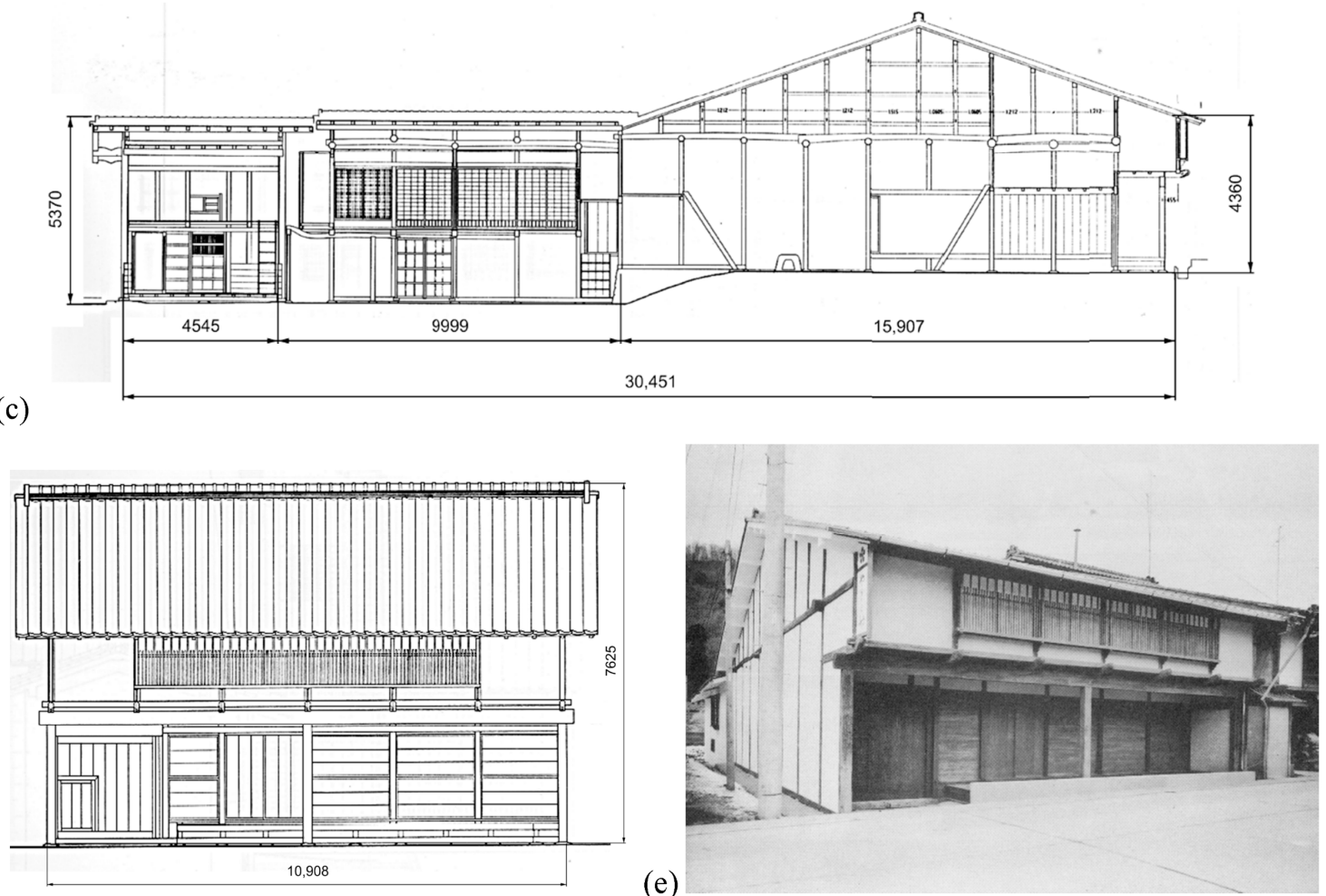

Figure 2. Sanayama residence (SA-RES) [67]: (a) ground floor plan (unit: $\mathrm{mm}$ ), (b) first floor plan, (c) AA' section, (d) south elevation, (d) façade and (e) state just after the restoration in 1977 (a picture taken from the south). ((a-d) modified by the authors). 
(a)

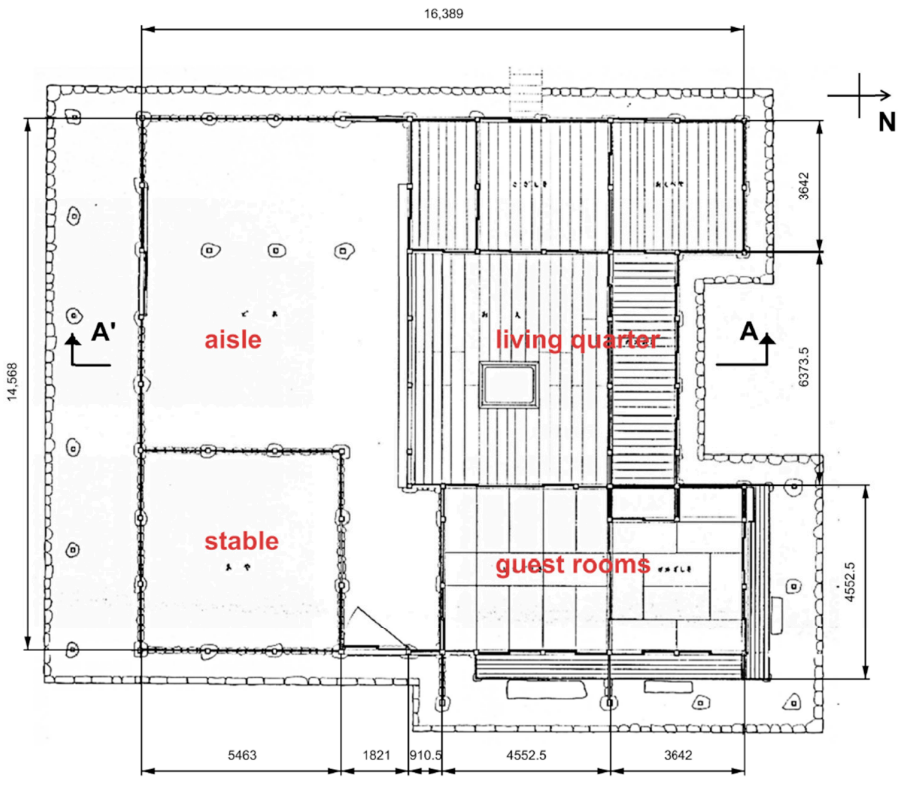

(b)

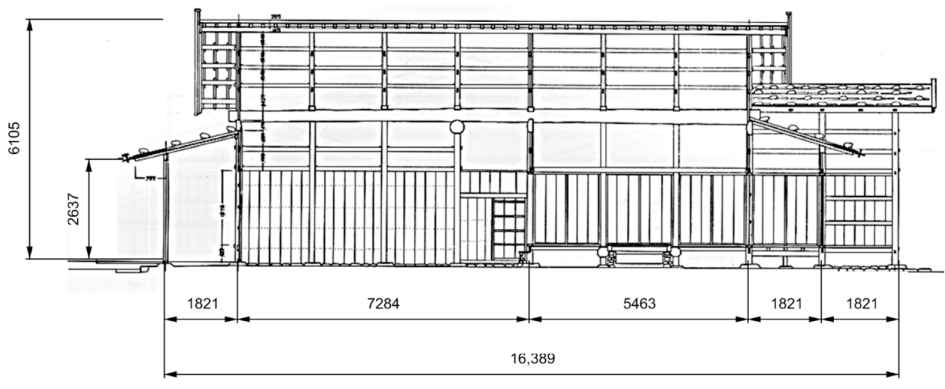

(c)

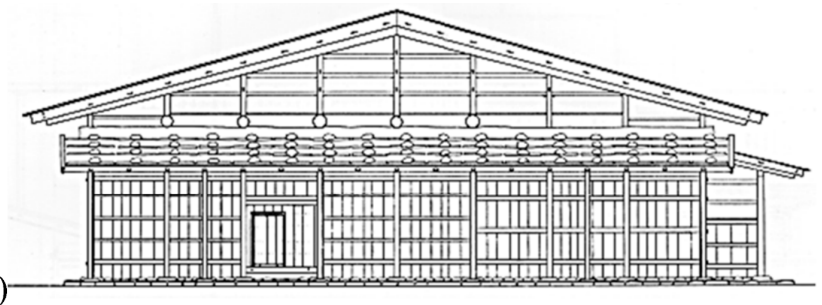

(d)
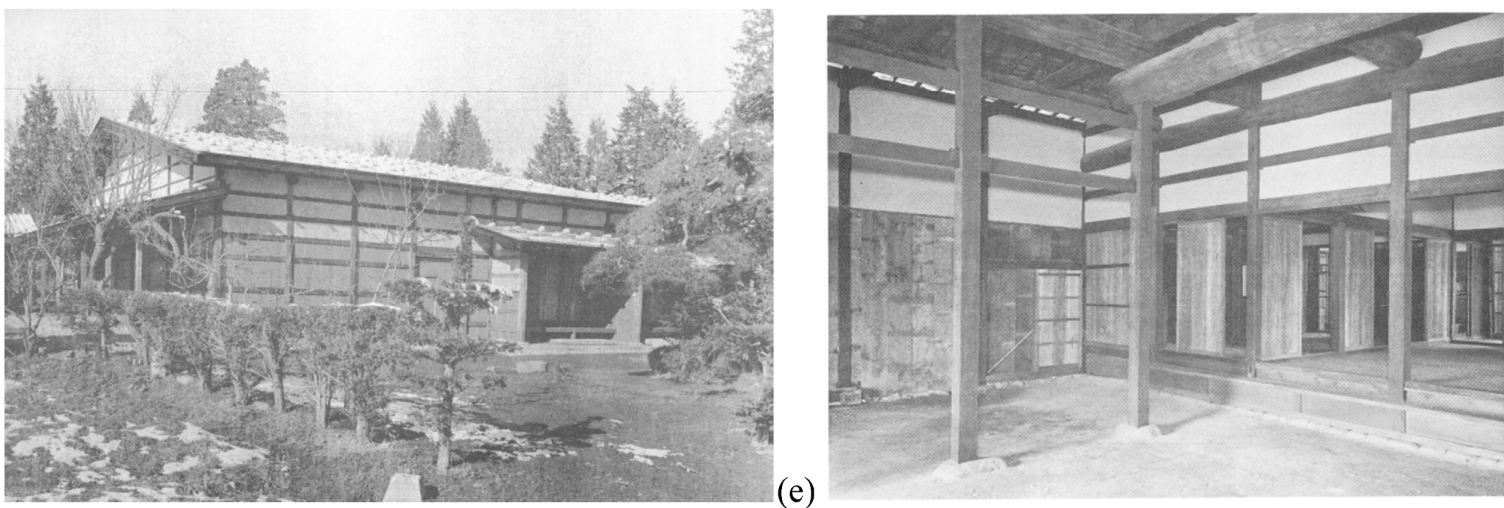

Figure 3. Sonehara residence (SO-RES) [68]: (a) ground floor plan (unit: mm), (b) AA' section, (c) east elevation, (d) state just after the restoration in 1977 (a picture taken from the southeast) and (e) interior view from the aisle ((a-c) modified by the authors). 
The structural frames are composed of cypress and cedar. The floors of the living quarter are covered with timber boards while those of the guest rooms with tatamis. The floors of the aisle and the stable are covered with earth. The floor level of the aisle and stable is the same as the ground level. The upper parts of the walls are composed of timber meshes covered with earth while the lower parts with timber panels (see Figure $2 \mathrm{c}$ ). The timber meshes of the walls are composed of pine and cypress. The timber panels of the walls are made of pine. The roofs are covered with multiple layers of timber planks. Such a construction technique was often used for traditional houses in Japan [72]. Stones are placed randomly over the timber planks to stabilise the roofs (see Figure $3 \mathrm{~d}$ ). The timber planks are made of pine and cypress.

\subsection{Description of the Restoration in 1977}

In Japan, the heritage buildings are controlled under the Law for the Protection of Cultural Properties [74]. The law was established in 1950. It only permits repair to restore the original state. Minor alteration might be exceptionally accepted to remove later additions or to adapt the use of today. The restoration of timber heritage buildings usually involves the dismantling and the reassembling of an entire or a partial building [65]. Both case studies were entirely dismantled and reassembled in 1977.

As for SA-RES, the project was aimed to be restored to the original state. Extremely damaged or deteriorated components were replaced with new ones although the original materials were kept as much as possible. For instance, the extremely damaged parts of timber beams or columns were cut, and the remaining parts were coupled with new timber. As the entire building was dismantled, the restoration involved all structural components. The building was assembled by construction techniques that were used for the original construction. Most of the ceramic tiles of the roofs were replaced due to their extensive damage. The amounts of used materials are presented, referring to the restoration report (Table 2). In the table, foundations include the floors of the aisle. Moderate repair was conducted on the foundations, taking into account their damage state. As walls were partially covered with wallpaper, their conditions were satisfactory. However, as lime plaster and earth covering were missing in eastern walls, extensive refurbishment was carried out. Creosote was used as wood preservative. The same approach was taken for the restoration of SO-RES. Only significantly damaged or deteriorated components were replaced with new ones. The roofs were restored to the original condition as they went through extensive modification over the years. The entire earthen floors of the aisle and the stable were refurbished. For this reason, a substantial amount of earth was required (see Table 2).

Operational energy use was calculated according to the method discussed in Section 2.2. The two houses showed close $\mathrm{U}_{\mathrm{A}}$ and $\eta$ values (Table 3). Table 4 presents the list of the domestic appliances considered for the calculation. They are selected based on the domestic appliances found in traditional houses [75,76]. The final energy consumption was $995.8 \mathrm{MJ} / \mathrm{m}^{2}$ year and 787.7 MJ/m² year for SA-RES and SO-RES, respectively. SA-RES showed a higher value than SO-RES in spite of similar $\mathrm{U}_{\mathrm{A}}$ values. The adopted calculation method takes into account room use. The gross floor area of SO-RES is larger than that of SA-RES. However, nearly half of the area of SO-RES is occupied by the aisle and the stable. SA-RES has more rooms for daily use including the reception and the guest rooms than SO-RES. According to the in-situ survey of the energy consumption of similar traditional timber-frame houses in Japan, comparable values were reported [76]. As the houses belong to cold alpine climate, heating was highly dominant (Figure 4a). It is noted that "others" in the figure denote the energy use of appliances that are not building-related. 
Table 2. Quantity estimation of used materials for the restoration of the heritage houses.

\begin{tabular}{|c|c|c|c|}
\hline Structural Components & Materials $\left(\mathrm{kg} / \mathrm{m}^{2}\right)$ & SA-RES & SO-RES \\
\hline \multirow{3}{*}{ foundations } & limestone & 23.1 & 54.3 \\
\hline & concrete & 30.4 & 95.5 \\
\hline & earth & - & 300.9 \\
\hline \multirow{3}{*}{ structural frames } & timber & 26.6 & 30.4 \\
\hline & iron nails & 1.2 & 1.0 \\
\hline & wood preservative & 0.6 & 0.3 \\
\hline \multirow{5}{*}{ roofs } & timber planks & 5.9 & 18.7 \\
\hline & stone & - & 21.9 \\
\hline & ceramic tiles & 61.5 & - \\
\hline & copper sheets & 0.2 & - \\
\hline & wood preservative & - & 0.6 \\
\hline \multirow{4}{*}{ walls } & bamboo mesh & 7.5 & - \\
\hline & timber & - & 3.3 \\
\hline & lime plaster & 3.8 & - \\
\hline & earth covering & 156.3 & 29.3 \\
\hline \multirow{2}{*}{ furnishings } & tatamis & 5.9 & 1.3 \\
\hline & partitions & 3.6 & 1.5 \\
\hline
\end{tabular}

Table 3. Heat transfer coefficients (HTCs) and solar heat gain coefficients (SHGCs) of the studied houses.

\begin{tabular}{cccc}
\hline & $\mathrm{U}_{\mathbf{A}}\left(\mathbf{W} / \mathbf{m}^{2} \cdot \mathbf{K}\right)$ & $\eta_{H}(\mathbf{\%})$ & $\eta_{C}(\mathbf{\%})$ \\
\hline SA-RES & 1.67 & 3.0 & 3.2 \\
\hline SO-RES & 1.65 & 2.6 & 3.1 \\
\hline 1980-RES & 1.27 & 2.9 & 3.3 \\
\hline 1992-RES & 1.09 & 2.6 & 3.0 \\
\hline 1999-RES & 0.43 & 1.6 & 2.2 \\
\hline
\end{tabular}

Table 4. List of domestic appliances considered for the estimation of the energy use.

\begin{tabular}{ccc}
\hline & Heritage Houses & Contemporary Houses \\
\hline cooling/heating & air conditioners & air conditioners \\
\hline water heating & gas water heating & gas water heating \\
\hline lighting & fluorescent lamps & LED lamps \\
\hline
\end{tabular}

\subsection{Description of the Contemporary House}

A two-storey house was chosen as the case study of new construction (Figure 3a). In this paper, it is named the contemporary house as a comparison to the heritage houses introduced in Section 3.1. A detailed description of the house can be found in the publication of [77]. It is situated in Nagano prefecture. It was built in 2016. The structure is composed of timber frames. The roofs are covered with galvalume panels. The walls are composed of plasterboards, cement siding and spray foam. The dimension of the ground floor is $14.0 \times 10.5 \mathrm{~m}^{2}$ in plan (Figure 5a). The height of the ground floor is $3.0 \mathrm{~m}$ while that of the first floor $2.7 \mathrm{~m}$ (Figure $5 \mathrm{~b}, \mathrm{c}$ ). The gross floor area is $213.0 \mathrm{~m}^{2}$. The ground floor 
consists of a living room, a kitchen and a principal bedroom. The first floor has bedrooms for family members and guests. The building was chosen as the case study for its typical room layout as a contemporary detached house in Japan [78,79]. The gross floor area is nearly twice larger than that of typical houses, which is about $125 \mathrm{~m}^{2}$ [78]. Thus, the contemporary house has a close gross floor area to the studied heritage buildings. Typical domestic appliances are installed as a contemporary house in Japan $[80,81]$ (see Table 4). Table 5 shows the amounts of principally used materials. As for timber, cedar was mainly used while pine was used as beams and joists. Interior timber panels were used as the interior decoration of the house.

(a)
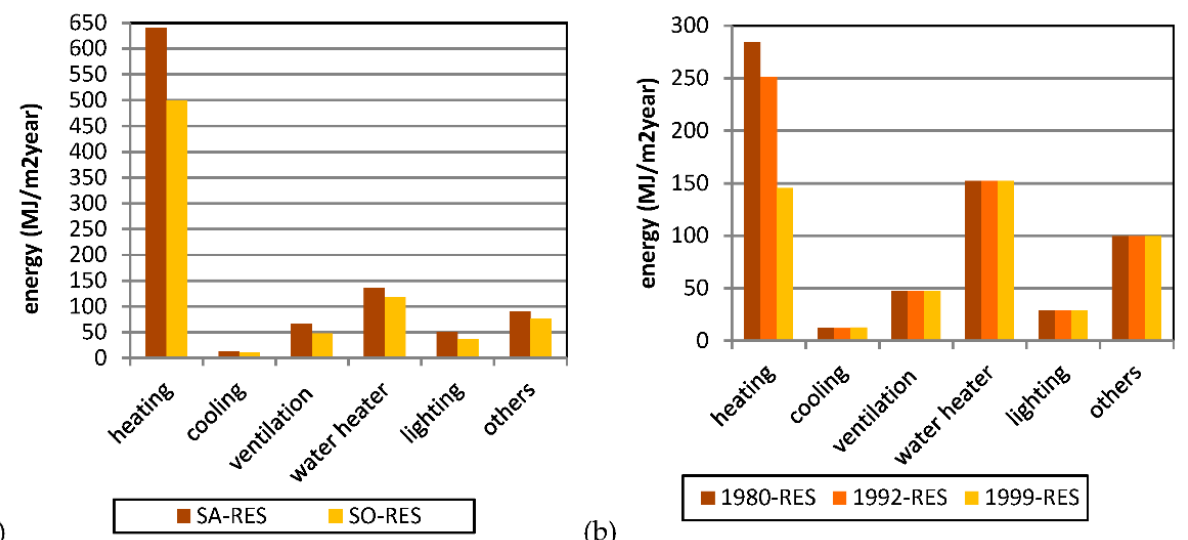

Figure 4. Estimation of energy use: (a) heritage houses and (b) contemporary houses.

(a)

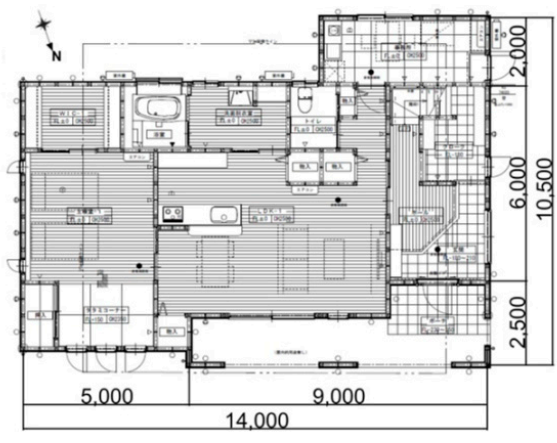

(b)
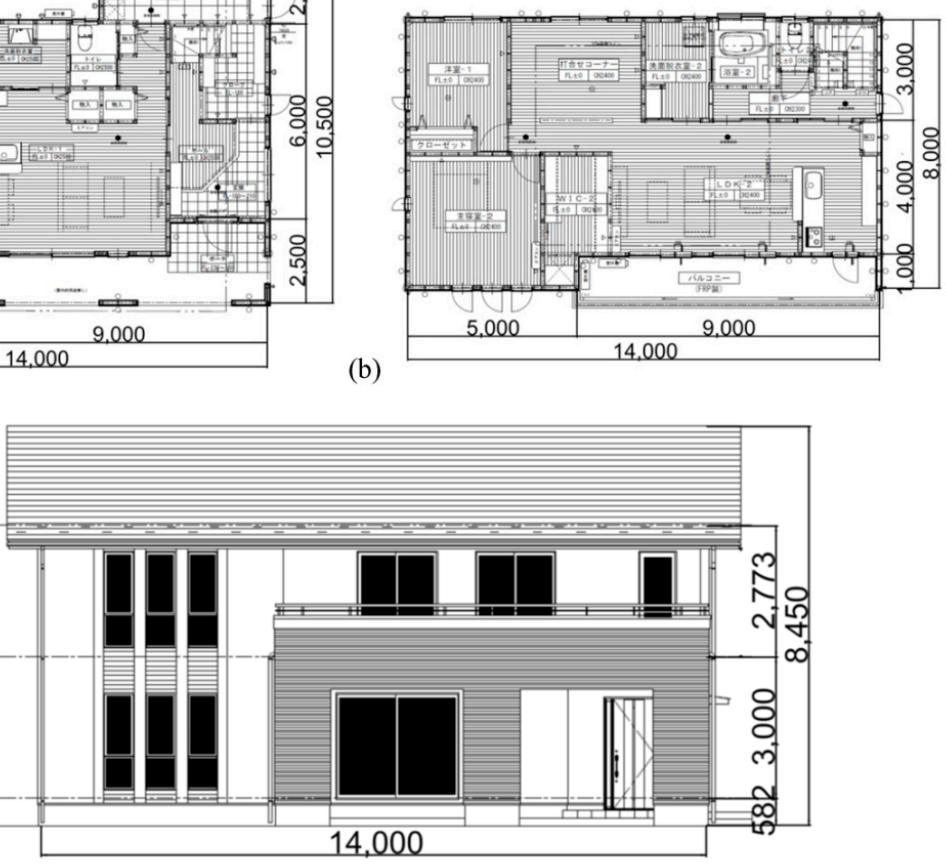

(c)

Figure 5. Contemporary house: (a) ground floor plan (unit: $\mathrm{mm}$ ), (b) first floor plan and (c) north elevation.

Operational energy use was calculated by the method discussed in Section 2.2. Taking into account the revisions of the energy-efficiency laws (EELs) in Japan, three conditions of the contemporary house were considered. The purpose was to examine the influences of insulation levels, considering very limited insulation levels of studied heritage buildings. 
EEL was revised in 1980, 1992 and 1999 [82]. It is noted that the real building was built in accordance with the 1999 EEL. According to the 1980, 1992 and 1999 EELs, they are named 1980 residence (1980-RES), 1992 residence (1992-RES) and 1999 residence (1999-RES) in this paper. It was assumed that the three houses (1980-RES, 1992-RES and 1999-RES) used spray foam equal to $262 \mathrm{~kg}, 358 \mathrm{~kg}$ and $1080 \mathrm{~kg}$ respectively. The amounts of the spray foam were determined to meet the criterion of the $U_{A}$ value specified by each EEL [82]. The $U_{A}$ and $\eta$ values are presented in Table 3. The $U_{A}$ value of 1999-RES is three times smaller than that of 1980-RES. The resultant energy use was $623.9 \mathrm{MJ} / \mathrm{m}^{2}$ year, $590.6 \mathrm{MJ} / \mathrm{m}^{2}$ year and $485.9 \mathrm{MJ} / \mathrm{m}^{2}$ year for 1980-RES, 1992-RES and 1999-RES, respectively. Water heating and lighting were the same among the three houses as they were not influenced by the insulation levels (Figure 4b).

Table 5. Quantity estimation of used materials of the contemporary house.

\begin{tabular}{ccc}
\hline Structural Components & Materials $\left(\mathbf{k g} / \mathbf{m}^{2}\right)$ & Contemporary House \\
\hline \multirow{2}{*}{ foundations } & concrete & 519.8 \\
\cline { 2 - 3 } & aggregate & 181.7 \\
\cline { 2 - 3 } & steel reinforcement & 13.4 \\
\hline \multirow{2}{*}{ structural frames } & timber & 96.6 \\
\hline \multirow{2}{*}{ roofs } & galvalume panels & 8.6 \\
\cline { 2 - 3 } & timber planks & 2.6 \\
\cline { 2 - 3 } & cement siding & 25.4 \\
\cline { 2 - 3 } & lime plasterboards & 17.1 \\
\hline \multirow{2}{*}{ furnishings } & glass & 2.7 \\
\cline { 2 - 3 } & tatamis & 0.4 \\
\hline
\end{tabular}

\section{Results of LCA}

\subsection{Results of Heritage Houses}

Table 6 presents the primary energy consumption and the gas emissions $\left(\mathrm{CO}_{2}, \mathrm{SOx}\right.$ and NOx). Comparison is made between SA-RES and SO-RES. SA-RES showed higher values in each indicator than SO-RES. As for the $\mathrm{CO}_{2}$ emissions, the difference was due to the restoration of the roofs. The roofs of SA-RES are covered with ceramic tiles while those of SO-RES with timber planks and stones. Nearly $61.6 \mathrm{~kg} / \mathrm{m}^{2}$ of the ceramic tiles were used for the restoration of the roofs of SA-RES. No CFC emissions were shown.

Table 6. Life-cycle assessment (LCA) results of the studied houses.

\begin{tabular}{|c|c|c|c|c|}
\hline & $\begin{array}{c}\text { Energy } \\
\left(\mathrm{MJ} / \mathrm{m}^{2} \text { year }\right)\end{array}$ & $\begin{array}{c}\mathrm{CO}_{2} \\
\left(\mathrm{~kg}-\mathrm{CO}_{2} \mathrm{eq} / \mathrm{m}^{2} \text { year }\right)\end{array}$ & $\begin{array}{c}\mathrm{SOx} \\
\left(\mathrm{kg}-\mathrm{SO}_{2} \text { eq/m } / \mathrm{m}^{2} \text { year }\right)\end{array}$ & $\begin{array}{c}\mathrm{NOx} \\
\left(\mathrm{g}-\mathrm{NO}_{2} \mathrm{eq} / \mathrm{m}^{2} \text { year }\right)\end{array}$ \\
\hline SA-RES & 3028.7 & 169.3 & 130.8 & 279.6 \\
\hline SO-RES & 2226.7 & 131.2 & 113.4 & 215.9 \\
\hline 1980-RES & 1750.6 & 106.7 & 84.2 & 176.9 \\
\hline 1992-RES & 1672.0 & 102.1 & 81.2 & 169.7 \\
\hline 1999-RES & 1429.2 & 88.2 & 71.9 & 147.7 \\
\hline
\end{tabular}

Two sensitivity analyses were performed. The first one considered different selections of materials as there are a variety of choices in the database for timber, stone and ceramic tiles. The coefficient of variation (COV) of SA-RES was $27.7 \%, 24.8 \%$ and $0.0 \%$ for the construction, maintenance and replacement phases in turn (Figure 6a) while the COV of SO-RES was $26.3 \%, 12.6 \%$ and $7.2 \%$ (Figure $6 \mathrm{~b}$ ). In both cases, the construction and maintenance phases showed similar COV values. The replacement phase of SA-RES was 
not influenced by the material choices as the roofs of SA-RES were not replaced during the reference study period. On the other hand, the replacement phase of SO-RES showed a deviation due to the replacement of the timber-plank roofs. The replacement of the timberplank roofs was necessary during the study period since their service life was considered as 30 years (see Table 1). The other indicators (energy, NOx, SOx) showed similar results to $\mathrm{CO}_{2}$.

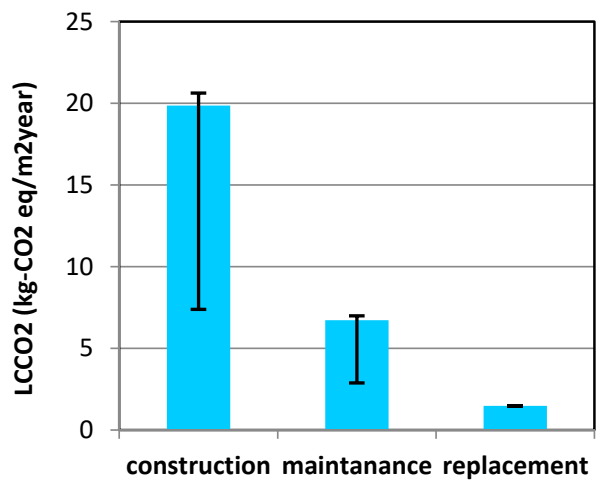

(a)

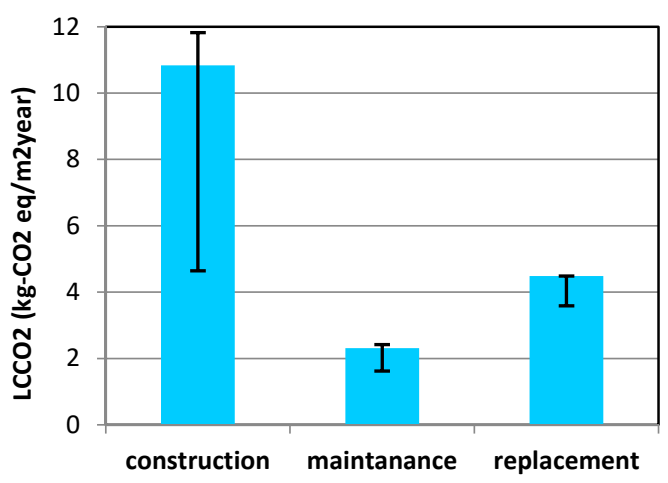

(b)

Figure 6. Life-cycle $\mathrm{CO}_{2}\left(\mathrm{LCCO}_{2}\right)$ of the construction, maintenance and replacement phases: (a) SA-RES and (b) SO-RES.

The second sensitivity analysis was conducted by proposing different technical systems. Two combinations of the technical systems were proposed (Table 7). Proposed technical system 1 (PTS1) considered that the studied houses were equipped only with electrical appliances. Proposed technical system 2 (PTS2) considered an advanced technical system. It includes a polymer electrolyte fuel cell (PEFC) cogeneration system and a heat exchange system. The two systems were determined, taking into account domestic appliances found in typical contemporary houses in Japan [83,84]. In addition, they can be easily removed and have limited impacts on the appearance of heritage buildings. The results of PTS1 and PTS2 are compared with the reference cases which were presented above (Table 8). PTS1 saved around $6.0 \%$ of energy compared to the reference case in both heritage buildings while PTS2 $10.0 \%$ (Figure 7). The other indicators $\left(\mathrm{CO}_{2}, \mathrm{SOx}\right.$ and NOx) showed similar reduction rates.

(a)

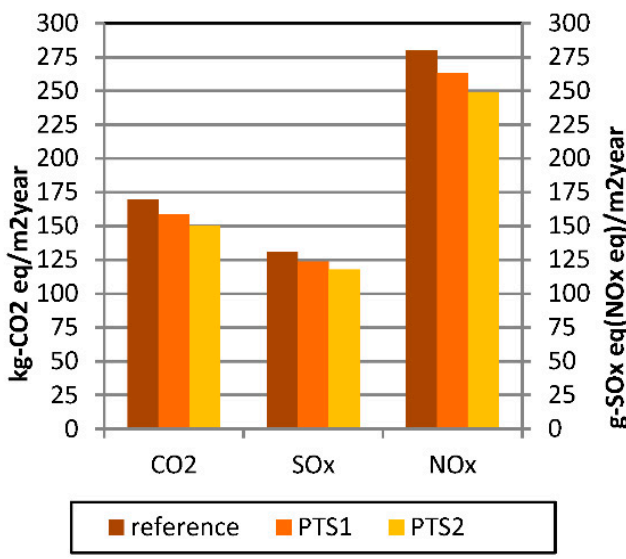

(b)

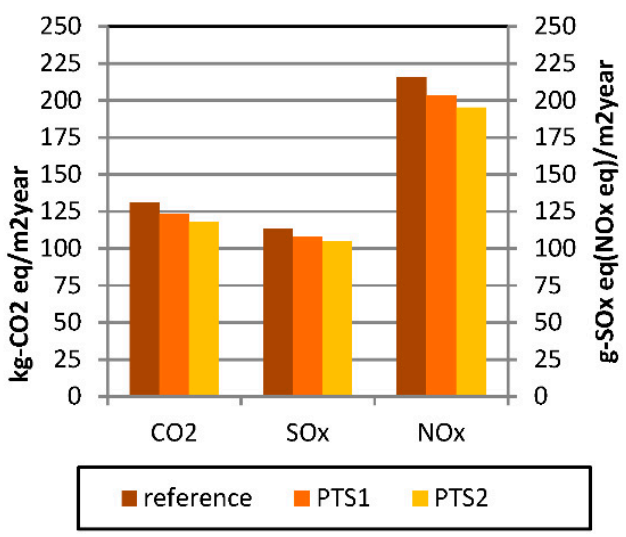

Figure 7. Environmental impacts of the heritage houses with different technical systems: (a) SA-RES and (b) SO-RES. 
Table 7. Proposed technical systems.

\begin{tabular}{ccc}
\hline & $\begin{array}{c}\text { Proposed Technical System 1 } \\
\text { (PTS1) }\end{array}$ & $\begin{array}{c}\text { Proposed Technical System 2 } \\
\text { (PTS2) }\end{array}$ \\
\hline cooling/heating & air conditioners & air conditioners \\
\hline water heating & $\mathrm{CO}_{2}$ heat pump system & PEFC cogeneration system \\
\hline lighting & LED lamps & LED lamps \\
\hline
\end{tabular}

Table 8. Comparison of LCA results of the studied houses between different technical systems.

\begin{tabular}{|c|c|c|c|}
\hline SA-RES & Reference & PTS1 & PTS2 \\
\hline energy (MJ/m²year) & 3028.7 & 2845.9 & 2693.8 \\
\hline $\mathrm{CO}_{2}\left(\mathrm{~kg}-\mathrm{CO}_{2} \mathrm{eq} / \mathrm{m}^{2}\right.$ year $)$ & 169.3 & 158.8 & 150.0 \\
\hline $\mathrm{SOx}\left(\mathrm{g}-\mathrm{SO}_{2} \mathrm{eq} / \mathrm{m}^{2}\right.$ year$)$ & 130.8 & 123.6 & 117.7 \\
\hline $\mathrm{NOx}$ (g-NO $\mathrm{NO}_{2} \mathrm{eq} / \mathrm{m}^{2}$ year) & 279.6 & 263.0 & 249.1 \\
\hline SO-RES & reference & PTS1 & PTS2 \\
\hline energy (MJ/m²year) & 2226.7 & 2088.3 & 1999.4 \\
\hline $\mathrm{CO}_{2}\left(\mathrm{~kg}-\mathrm{CO}_{2} \mathrm{eq} / \mathrm{m}^{2}\right.$ year $)$ & 131.2 & 123.2 & 118.1 \\
\hline $\mathrm{SOx}\left(\mathrm{g}-\mathrm{SO}_{2} \mathrm{eq} / \mathrm{m}^{2}\right.$ year$)$ & 113.4 & 107.9 & 104.5 \\
\hline $\mathrm{NOx}$ (g-NO $\mathrm{NO}_{2}$ eq/m²year) & 215.9 & 203.3 & 195.2 \\
\hline 1980-RES & reference & PTS1 & PTS2 \\
\hline energy (MJ/m²year) & 1750.6 & 1594.3 & 1536.2 \\
\hline $\mathrm{CO}_{2}\left(\mathrm{~kg}-\mathrm{CO}_{2} \mathrm{eq} / \mathrm{m}^{2}\right.$ year $)$ & 106.7 & 97.7 & 94.3 \\
\hline $\mathrm{SOx}\left(\mathrm{g}-\mathrm{SO}_{2} \mathrm{eq} / \mathrm{m}^{2}\right.$ year $)$ & 84.2 & 78.1 & 75.8 \\
\hline $\mathrm{NOx}$ (g-NO $\mathrm{NO}_{2} \mathrm{eq} / \mathrm{m}^{2}$ year) & 176.9 & 162.7 & 157.4 \\
\hline 1992-RES & reference & PTS1 & PTS2 \\
\hline energy (MJ/m²year) & 1672.0 & 1521.6 & 1463.5 \\
\hline $\mathrm{CO}_{2}\left(\mathrm{~kg}-\mathrm{CO}_{2} \mathrm{eq} / \mathrm{m}^{2}\right.$ year $)$ & 102.1 & 93.4 & 90.1 \\
\hline $\mathrm{SOx}\left(\mathrm{g}-\mathrm{SO}_{2} \mathrm{eq} / \mathrm{m}^{2}\right.$ year$)$ & 81.2 & 75.3 & 73.0 \\
\hline $\mathrm{NOx}$ (g-NO $\mathrm{NO}_{2} \mathrm{eq} / \mathrm{m}^{2}$ year) & 169.7 & 156.0 & 150.7 \\
\hline 1999-RES & reference & PTS1 & PTS2 \\
\hline energy (MJ/m²year) & 1429.2 & 1290.8 & 1250.7 \\
\hline $\mathrm{CO}_{2}\left(\mathrm{~kg}-\mathrm{CO}_{2} \mathrm{eq} / \mathrm{m}^{2}\right.$ year $)$ & 88.2 & 80.2 & 77.9 \\
\hline $\mathrm{SOx}\left(\mathrm{g}-\mathrm{SO}_{2} \mathrm{eq} / \mathrm{m}^{2}\right.$ year$)$ & 71.9 & 66.5 & 64.9 \\
\hline $\mathrm{NOx}\left(\mathrm{g}-\mathrm{NO}_{2}\right.$ eq $/ \mathrm{m}^{2}$ year$)$ & 147.7 & 135.1 & 131.5 \\
\hline
\end{tabular}

\subsection{Results of Contemporary Houses}

LCA was applied to 1980-RES, 1992-RES and 1999-RES. Table 6 shows that the results were influenced by insulation levels. The $\mathrm{CO}_{2}$ emissions of the construction phase were increased as an amount of spray foam was added. However, it decreased the $\mathrm{CO}_{2}$ emissions of the operation phase. The CFC emissions of 1980-RES, 1992-RES and 1999-RES were 3.3, 4.5 and $11.3 \mathrm{~g}$-CFC11/ $\mathrm{m}^{2}$ year, respectively. The values were increased according to the amount of the spray foam. Sensitivity analysis was performed to study the environmental impacts of operational energy use. The same two systems as the heritage houses were examined (see Table 7). PTS1 decreased 9.0\% of the energy use on average while PTS2 10\% (see Table 8). 


\subsection{Comparison of Results between Heritage Houses and Contemporary Houses}

Results are compared between restoration projects and new construction. Table 9 presents the quantity of principally used materials and the values of the indicators of the construction phase. In the table, mineral-based materials denote stones, earth, lime and cement. Timber includes bamboo. The new construction consumed more mineralbased materials than the restoration projects. It is added that SO-RES used nearly twice as much mineral-based materials as SA-RES. However, SO-RES had a lower value of the $\mathrm{CO}_{2}$ emissions than SO-RES. As discussed in Section 3.2, SO-RES consumed a substantial amount of earth for the aisle floors $\left(300.9 \mathrm{~kg} / \mathrm{m}^{2}\right)$. SA-RES used $61.6 \mathrm{~kg} / \mathrm{m}^{2}$ of ceramic tiles for the roofs. In the considered database, ceramic tiles emit a significant amount of $\mathrm{CO}_{2}$ due to the burning process, compared to earth $\left(1.72 \mathrm{~kg}-\mathrm{CO}_{2} \mathrm{eq} / \mathrm{kg}\right.$ vs. $\left.0.018 \mathrm{~kg}-\mathrm{CO}_{2} \mathrm{eq} / \mathrm{kg}\right)$. Since the restoration projects aimed to keep the original materials as much as possible, a smaller amount of new timber was used $\left(43.6 \mathrm{~kg} / \mathrm{m}^{2}\right.$ and $53.9 \mathrm{~kg} / \mathrm{m}^{2}$ for SA-RES and SO-RES, in turn) than the contemporary house $\left(105.5 \mathrm{~kg} / \mathrm{m}^{2}\right)$. However, the heritage houses showed higher $\mathrm{CO}_{2}$ emissions than the contemporary houses. The studied heritage houses required specific timber materials (e.g., Japanese cypress), as it ended in high $\mathrm{CO}_{2}$ emissions. The contemporary house consumes most mineral-based materials such as concrete and aggregate for foundations $\left(701.5 \mathrm{~kg} / \mathrm{m}^{2}\right)$.

Table 9. Quantity of primary used materials and values of the indicators of the construction phase.

\begin{tabular}{|c|c|c|c|c|c|c|c|}
\hline & $\begin{array}{l}\text { Timber } \\
\left(\mathrm{kg} / \mathrm{m}^{2}\right)\end{array}$ & $\begin{array}{c}\text { Mineral-Based } \\
\text { Materials } \\
\left(\mathrm{kg} / \mathrm{m}^{2}\right)\end{array}$ & $\begin{array}{c}\text { Metal } \\
\left(\mathrm{kg} / \mathrm{m}^{2}\right)\end{array}$ & $\begin{array}{c}\text { Energy } \\
\text { (MJ/m² year) }\end{array}$ & $\begin{array}{c}\mathrm{CO}_{2} \\
\left(\mathrm{~kg}-\mathrm{CO}_{2}\right. \\
\left.\text { eq/m } / \mathrm{m}^{2} \text { year }\right)\end{array}$ & $\begin{array}{c}\mathrm{SOx} \\
\left(\mathrm{g}-\mathrm{SO}_{2}\right. \\
\left.\text { eq/m² } / \mathrm{m}^{2} \text { year }\right)\end{array}$ & $\begin{array}{c}\mathrm{NOx} \\
\left(\mathrm{g}-\mathrm{NO}_{2}\right. \\
\left.\text { eq/m } / \mathrm{m}^{2} \text { year }\right)\end{array}$ \\
\hline SA-RES & 43.6 & 284.0 & 1.4 & 341.0 & 19.6 & 23.2 & 41.1 \\
\hline SO-RES & 53.9 & 501.9 & 1.0 & 164.7 & 10.7 & 21.0 & 23.5 \\
\hline 1999-RES & 105.5 & 752.1 & 22.0 & 120.8 & 9.6 & 12.5 & 21.2 \\
\hline
\end{tabular}

The yearly $\mathrm{LCCO}_{2}$ of the gross floor area is compared among the studied houses. The heritage houses showed nearly twice as high values as 1999-RES (Figure 8a). The difference was mainly due to the operation phase. However, the $\mathrm{CO}_{2}$ emissions of the construction phase of the heritage houses were higher than those of the contemporary houses. The ratios of the $\mathrm{CO}_{2}$ emissions of each stage are compared (Figure $8 \mathrm{~b}$ ). Similar ratios were observed among the five cases as the operational energy use was dominant in $\mathrm{LCCO}_{2}$. The heritage houses consumed much more energy than the contemporary houses due to limited insulation levels. However, in the performed LCA, the calculation of the $\mathrm{U}_{\mathrm{A}}$ and $\eta$ values included assumptions. The energy consumption may be estimated more accurately with the $\mathrm{U}_{\mathrm{A}}$ and $\eta$ values which are experimentally evaluated. It is obvious that with insulation materials installed, heritage buildings can save operational energy use. However, such alteration requires very deliberate discussion or even is prohibitable. It may be effective to propose appropriate technical systems for the reduction in operational energy use as discussed in Section 4.1. 

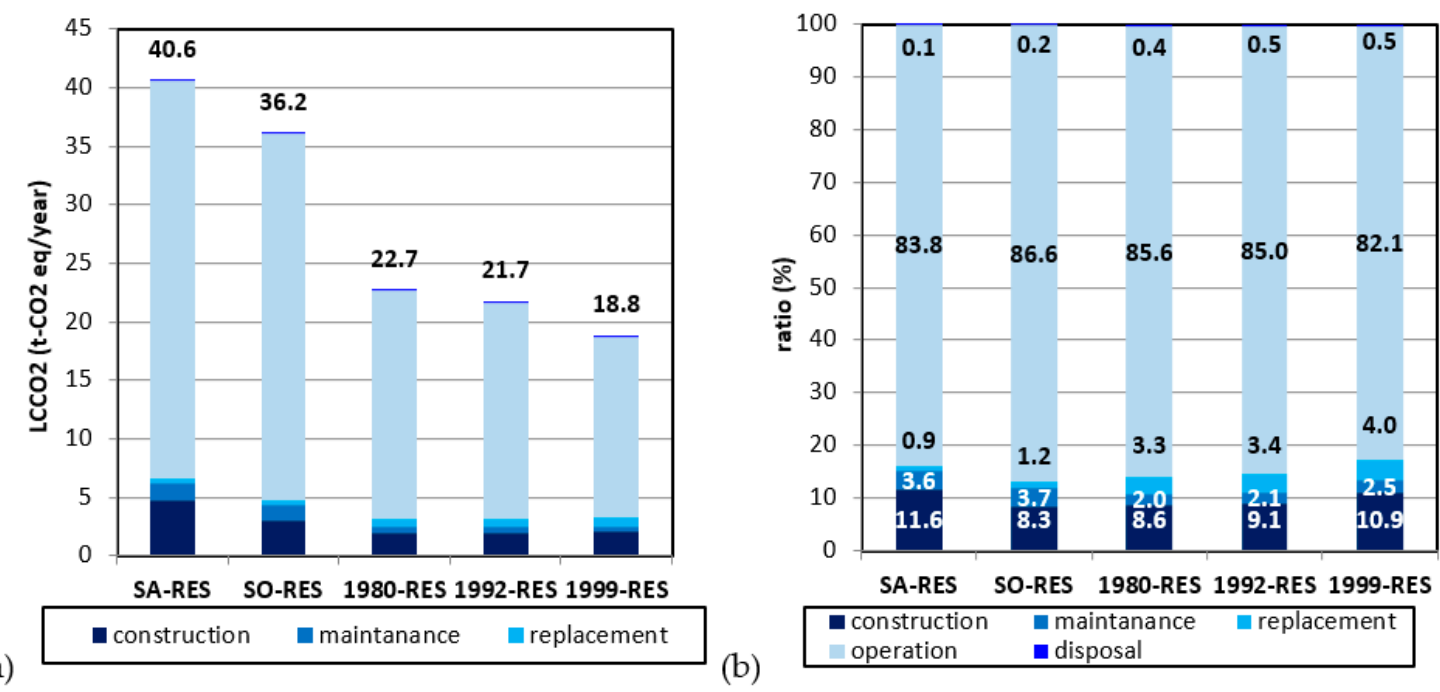

Figure 8. Yearly $\mathrm{LCCO}_{2}$ of the studied houses: (a) yearly $\mathrm{CO}_{2}$ emissions and (b) their ratios.

An additional analysis was performed by considering a different reference study period. In this analysis, the considered study period was 100 years. The study period changed $\mathrm{LCCO}_{2}$ values slightly (Figure 9a). As for the heritage houses, $\mathrm{LCCO}_{2}$ of the operation phase took up around $90 \%$ (Figure $9 \mathrm{~b}$ ). The contemporary houses showed almost the same results as the previous case (see Figure 8).
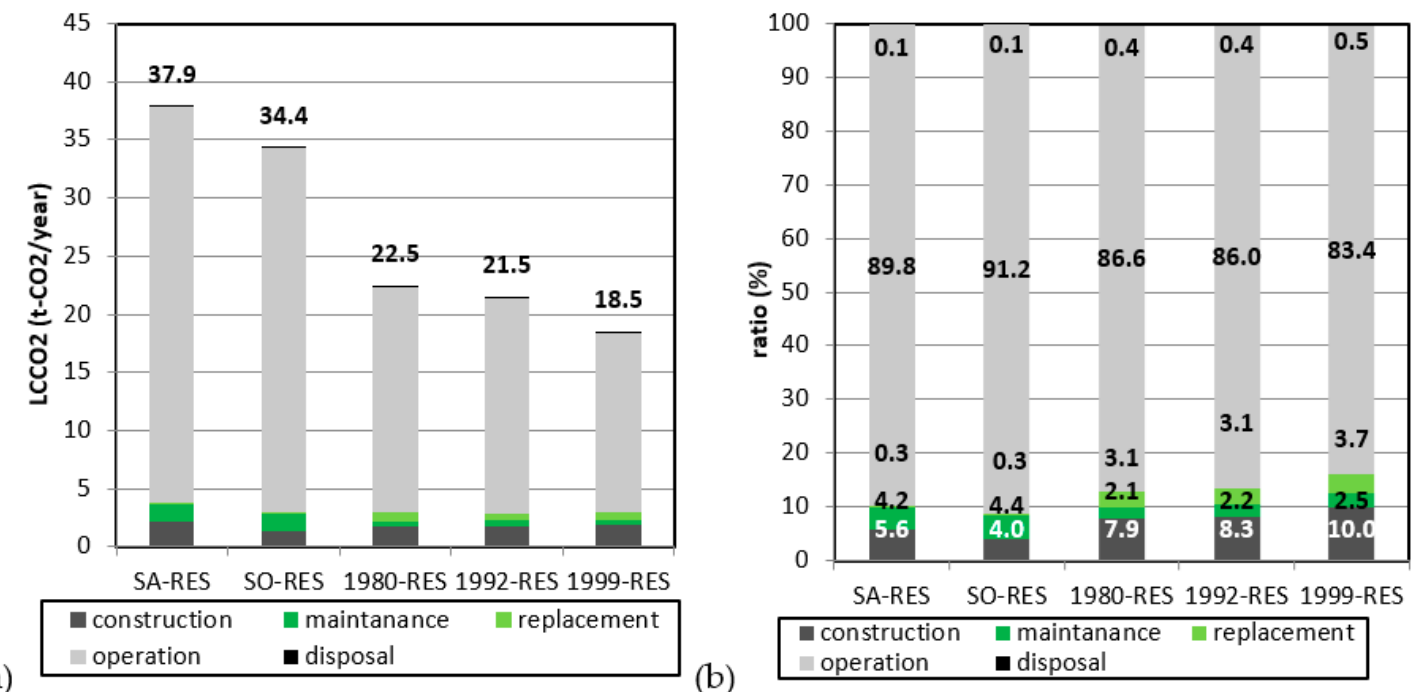

Figure 9. $\mathrm{LCCO}_{2}$ of the studied houses for the reference study period of 100 years: (a) yearly $\mathrm{CO}_{2}$ emissions and (b) their ratios.

\section{Discussion}

\subsection{Application of LCA to Conservation Projects of Heritage Buildings}

The paper discussed the environmental impacts of restoration projects by means of LCA. The adopted LCA quantified the environmental performance of the restoration of heritage buildings. In the present research, a database based on inter-industry relationships was used. However, the inter-industry relationships may not be adequate for the estimation of the greenhouse gas emissions of materials that do not frequently appear in the market. It is often the case with restoration projects as they often use particular traditional materials which are not utilised for typical contemporary construction. Results were influenced by the service lives of structural components. This implies that the environmental performance of heritage buildings can be improved by materials that last longer periods. It is noted 
that the reference study period had a limited influence on the studied buildings as the operational energy use was dominant.

\subsection{Comparison of Energy Consumption between the Case Studies}

In the present study, two types of case studies were compared. The adopted LCA methodology indicated the results were highly influenced by operational energy use. In other words, as far as energy efficiency was concerned, heritage buildings were less preferable than contemporary buildings. However, it is worthwhile noting that the energy consumption was highly related to the use of heating since the buildings belong to cold alpine climate. However, for the reliable estimation of the energy consumption of heritage buildings, the heat transfer coefficients of traditional materials need to be experimentally examined. In the present study, due to the lack of experimental evidence, their heat transfer coefficients were calculated, referring to the thermal conductivities of similar materials. It is added that the concept of rooms is not the same as contemporary houses. Some rooms serve different purposes. For instance, an aisle is not only a corridor but also a kitchen. Partitions between rooms can be removed so that many people are accommodated in one large space. Such room use may not have been adequately included in the adopted calculation method. Different technical systems were proposed and examined including a cogeneration system and a heat exchange system. They reduced operational energy use. However, further study is necessary to examine the effectiveness of such technical systems on heritage buildings.

\section{Concluding Remarks}

This paper applied LCA to the construction of contemporary buildings and the restoration of heritage buildings. A challenge was found in the choices of materials from a database since the used database mainly covers materials for the construction of contemporary buildings. Sensitivity analysis showed that results were influenced by the choices of materials in the database. For the accurate estimation of the $\mathrm{LCCO}_{2}$ of restoration projects, it is advisable to prepare proper databases for traditional materials although such a task is not straightforward.

The environmental impacts of heritage buildings were highly attributed to operational energy use. It may be worthwhile to install proper technical systems to reduce operational energy use. As one of the advantages of the restoration of heritage buildings, a limited amount of materials is required since the original materials are kept as much as possible. It results in a reduction in the disposal of waste.

This paper showed that further investigation is necessary for appropriate LCA application to heritage buildings. It can be beneficial to apply LCA to heritage buildings positioned in different climate zones from the one considered in this study. In addition, it is suggested to examine the applicability of LCA to different types of restoration projects. For instance, the strengthening of heritage buildings would be interesting since it needs to deal with the improvements of structural safety as well as the protection of cultural value and the reduction in environmental impacts at the same time.

Author Contributions: Conceptualization, Y.E. and H.T.; methodology, Y.E. and H.T.; analysis, Y.E. and H.T.; writing-original draft preparation, Y.E.; writing-review and editing, Y.E. and H.T.; visualization, Y.E.; supervision, Y.E. and H.T. All authors have read and agreed to the published version of the manuscript.

Funding: This research received no external funding.

Informed Consent Statement: Not applicable.

Data Availability Statement: Not applicable.

Conflicts of Interest: The authors report no potential conflict of interest. 


\section{References}

1. Bartlett, A.A. Reflections on Sustainability, Population Growth, and the Environment. Popul. Environ. 1994, 16, 5-35. [CrossRef]

2. Report of the World Commission on Environment and Development: Our Common Future; UN Documents; United Nations (UN): New York, NY, USA, 1987.

3. Pope, J.; Annandale, D.; Morrison-Saunders, A. Conceptualising Sustainability Assessment. Environ. Impact Assess. Rev. 2004, 24, 595-616. [CrossRef]

4. Sustainability in Buildings and Civil Engineering Works-General Principles; International Organization for Standardization (ISO) ISO15392; International Organization for Standardization: Genève, Switzerland, 2019.

5. Environmental Design; International Federation for Structural Concrete (FIB): Lausanne, Switzerland, 2004.

6. Bragança, L.; Mateus, R.; Koukkari, H. Building Sustainability Assessment. Sustainability 2010, 2, 2010-2023. [CrossRef]

7. Koukkari, H.; Brangança, L. Review on the European Strategies for Energy-efficient Buildings. Int. J. Sustain. Build. Technol. Urban Dev. 2011, 2, 87-99. [CrossRef]

8. The European Environment-State and Outlook 2020. Knowledge for Transition to a Sustainable Europe; European Environment Agency, Publications Office of the European Union: Luxembourg, 2019.

9. Cities of Tomorrow-Action Today. URBACT II Capitalisation. Building Energy Efficiency in European Cities; Moulin, E. (Ed.) URBACT: Saint-Denis, France, 2013.

10. Report of the United Nations conference on human settlements (HABITAT II). In Proceedings of the Habitat II Conference on Human Settlements, Istanbul, Turkey, 3-4 June 1996.

11. Elsorady, D. Sustainability and Conserved Energy Value of Heritage Buildings. Renew. Energy Sustain. Dev. 2017, 3, 104-117. [CrossRef]

12. Munarim, U.; Ghisi, E. Environmental Feasibility of Heritage Buildings Rehabilitation. Renew. Sustain. Energy Rev. 2016, 58, 235-249. [CrossRef]

13. Leeson, A.; Kirkham, A. THERE'S NO PLACE LIKE OLD HOMES Re-use and Recycle to Reduce Carbon; Historic England: London, UK, 2019.

14. Duffy, A.; Nerguti, A.; Purcell, C.E.; Cox, P. Understanding Carbon in the Historic Environment, Scoping Study, Final Report; Historic England: London, UK, 2019.

15. Menzies, G.F. Embodied Energy Considerations for Existing Buildings. Tech. Pap. 2011, 13, 53-68.

16. Karoglou, M.; Kyvelou, S.S.; Boukouvalas, C.; Theofani, C.; Bakolas, A.; Krokida, M.; Moropoulou, A. Towards a Preservationsustainability Nexus: Applying LCA to Reduce the Environmental Footprint of Modern Built Heritage. Sustainability 2019, 11, 6147. [CrossRef]

17. Berg, F.; Fuglseth, M. Life Cycle Assessment and Historic Buildings: Energy-efficiency Refurbishment versus New Construction in Norway. J. Archit. Conserv. 2018, 24, 152-167. [CrossRef]

18. Litti, G.; Audenaert, A.; Lavagna, M. Life Cycle Operating Energy Saving from Windows Retrofitting in Heritage Buildings Accounting for Technical Performance Decay. J. Build. Eng. 2018, 17, 135-153. [CrossRef]

19. Napolano, L.; Menna, C.; Asprone, D.; Prota, A.; Manfredi, G. LCA-based Study on Structural Retrofit Options for Ma-sonry Buildings. Int. J. Life Cycle Assess. 2015, 20, 23-35. [CrossRef]

20. De Cózar, J.C.G.; Martínez, A.G.; López, Í.A.; Alfonsea, M.R. Life Cycle Assessment as a Decision-making Tool for Selecting Building Systems in Heritage Intervention: Case Study of Roman Theatre in Itálica, Spain. J. Clean. Prod. 2019, 206, 27-39. [CrossRef]

21. Biondini, F.; Tattoni, S.; Titi, A. Life-cycle Structural Assessment of Industrial Heritage Buildings. In Life-Cycle of Engineering Systems: Emphasis on Sustainable Civil Infrastructure. In Proceedings of the Fifth International Symposium on Life-Cycle Civil Engineering (IALCCE 2016), Delft, The Netherlands, 16-19 October 2016; CRC Press: Delft, The Netherlands, 2016 ; p. 163.

22. Cinieri, V.; Zamperini, E. Lifecycle Oriented Approach for Sustainable Preservation of Historical Built Heritage. In Proceedings of the Online Conference Built Heritage 2013, Monitoring Conservation and Management, Milan, Italy, 18-20 November 2013; Boriani, M., Gabaglio, R., Gulotta, D., Eds.; pp. 465-474.

23. Ferreira, J.; Pinheiro, M.D.; De Brito, J. Economic and Environmental Savings of Structural Buildings Refurbishment with Demolition and Reconstruction-A Portuguese Benchmarking. J. Build. Eng. 2015, 3, 114-126. [CrossRef]

24. Guidelines for Life-cycle Assessment: A "Code of Practice". In Proceedings of the Society of Environmental Toxicology and Chemistry (SETAC) Workshop, Sesimbra, Portugal, 31 March-3 April 1993.

25. Tao, X.; Wu, Q. Energy Consumption and CO2 Emissions in Hinterland Container Transport. J. Clean. Prod. 2021, $279,123394$. [CrossRef]

26. Sepasgozar, S.M.; Li, H.; Shirowzhan, S.; Tam, V.W. Methods for Monitoring Construction Off-road Vehicle Emissions: A Critical Review for Identifying Deficiencies and Directions. Environ. Sci. Pollut. Res. 2019, 26, 15779-15794. [CrossRef]

27. Khasreen, M.M.; Banfill, P.F.; Menzies, G.F. Life-cycle Assessment and the Environmental Impact of Buildings: A Review. Sustainability 2009, 1, 674-701. [CrossRef]

28. Sustainability of Construction Works-Sustainability Assessment of Buildings-Part 1: General Framework; European Committee for Standardization (CEN) EN15643-1: Brussel, Belgium, 2010.

29. Sustainability of Construction Works- Assessment of Environmental Performance of Buildings-Calculation Method; European Committee for Standardization (CEN) EN15978: Brussel, Belgium, 2011. 
30. LCA Principles for Buildings; Architectural Institute of Japan (AIJ): Tokyo, Japan, 2013.

31. Piroozfar, P.; Pomponi, F.; El-Alem, F. Life Cycle Environmental Impact Assessment of Contemporary and Traditional Housing in Palestine. Energy Build. 2019, 202, 109333. [CrossRef]

32. Turksezer, Z.I.; Lavagna, M. Il Life Cycle Thinking a Support Delle Strategie di Mitigazione e Adattamento ai Cambiamenti Climatici; Environmental LCA for Maintenance and Rehabilitation Activities on Structures under Risk: A Literature Review. In Proceedings of the XIII Convegno della Rete Italiana LCA; VIII Convegno dell'Associazione Rete Italiana LCA, Rome, Italy, 13-14 June 2019; ENEA: Rome, Italy, 2019; pp. 462-469.

33. Rodrigues, C.; Kirchain, R.; Freire, F.; Gregory, J. Streamlined Environmental and Cost Life-cycle Approach for Building Thermal Retrofits: A Case of Residential Buildings in South European Climates. J. Clean. Prod. 2018, 172, 2625-2635. [CrossRef]

34. Bertolin, C.; Loli, A. Sustainable Interventions in Historic Buildings: A Developing Decision Making Tool. J. Cult. Herit. 2018, 34, 291-302. [CrossRef]

35. Güleroğlu, S.K.; Karagüler, M.E.; Kahraman, İ; Umdu, E.S. Methodological Approach for Performance Assessment of Historical Buildings Based on Seismic, Energy and Cost Performance: A Mediterranean Case. J. Build. Eng. 2020, 31, 101372. [CrossRef]

36. Agliata, R.; Marino, A.; Mollo, L.; Pariso, P. Historic Building Energy Audit and Retrofit Simulation with Hemp-lime Plaster-A Case Study. Sustainability 2020, 12, 4620. [CrossRef]

37. Favre, D.; Padey, P.; Goulouti, K.; Lasvaux, S. Energy Saving Potentials in Historic Buildings' Renovations: To Which Extent is the Heating Demand Limit Value (SIA 380/1) Reachable and at Which Costs? J. Phys. Conf. Ser. 2019, 1343, 012181. [CrossRef]

38. Bottino-Leone, D.; Larcher, M.; Herrera-Avellanosa, D.; Haas, F.; Troi, A. Evaluation of Natural-based Internal Insulation Systems in Historic Buildings through a Holistic Approach. Energy 2019, 181, 521-531. [CrossRef]

39. Pakdel, A.; Ayatollahi, H.; Sattary, S. Embodied Energy and $\mathrm{CO}_{2}$ Emissions of Life Cycle Assessment (LCA) in the Traditional and Contemporary Iranian Construction Systems. J. Build. Eng. 2021, 39, 102310. [CrossRef]

40. Annibaldi, V.; Cucchiella, F.; De Berardinis, P.; Gastaldi, M.; Rotilio, M. An Integrated Sustainable and Profitable Approach of Energy Efficiency in Heritage Buildings. J. Clean. Prod. 2020, 251, 119516. [CrossRef]

41. Galatioto, A.; Ricciu, R.; Salem, T.; Kinab, E. Energy and Economic Analysis on Retrofit Actions for Italian Public Historic Buildings. Energy 2019, 176, 58-66. [CrossRef]

42. Galiano-Garrigós, A.; González-Avilés, A.; Rizo-Maestre, C.; Andújar-Montoya, M. Energy Efficiency and Economic Viability as Decision Factors in the Rehabilitation of Historic Buildings. Sustainability 2019, 11, 4946. [CrossRef]

43. Blundo, D.S.; Ferrari, A.M.; del Hoyo, A.F.; Riccardi, M.P.; Muiña, F.E.G. Improving Sustainable Cultural Heritage Restoration Work through Life Cycle Assessment Based Model. J. Cult. Herit. 2018, 32, 221-231. [CrossRef]

44. Palacios-Munoz, B.; Peuportier, B.; Gracia-Villa, L.; López-Mesa, B. Sustainability Assessment of Refurbishment vs. New Constructions by Means of LCA and Durability-based Estimations of Buildings Lifespans: A New Approach. Build. Environ. 2019, 160, 106203. [CrossRef]

45. Selicati, V.; Cardinale, N.; Dassisti, M. Evaluation of the Sustainability of Energy Retrofit Interventions on the Historical Heritage: A Case Study in the City of Matera, Italy. Int. J. Heat Technol. 2020, 38, 17-27. [CrossRef]

46. Di Giuseppe, E.; D’Orazio, M.; Du, G.; Favi, C.; Lasvaux, S.; Maracchini, G.; Padey, P. A Stochastic Approach to LCA of Internal Insulation Solutions for Historic Buildings. Sustainability 2020, 12, 1535. [CrossRef]

47. Buda, A.; Lavagna, M. LCA Methodology to Compare Alternative Retrofit Scenarios for Historic Buildings: A Review. In Proceedings of the 12th Italian LCA, Messina, Italy, 11-12 June 2018.

48. Toosi, H.A.; Lavagna, M.; Leonforte, F.; Claudio, D.E.L.; Niccolò, A.S.T.E. Life Cycle Sustainability Assessment in Building Energy Retrofitting; A Review. Sustain. Cities Soc. 2020, 60, 102248. [CrossRef]

49. Franzoni, E.; Volpi, L.; Bonoli, A. Applicability of Life Cycle Assessment Methodology to Conservation Works in Historical Building: The Case of Cleaning. Energy Build. 2020, 214, 109844. [CrossRef]

50. Häfliger, I.F.; John, V.; Passer, A.; Lasvaux, S.; Hoxha, E.; Saade, M.R.M.; Habert, G. Buildings Environmental Impacts' Sensitivity Related to LCA Modelling Choices of Construction Materials. J. Clean. Prod. 2017, 156, 805-816. [CrossRef]

51. Lacirignola, M.; Blanc, P.; Girard, R.; Pérez-López, P.; Blanc, I. LCA of Emerging Technologies: Addressing High Uncertainty on Inputs' Variability When Performing Global Sensitivity Analysis. Sci. Total Environ. 2017, 578, 268-280. [CrossRef]

52. Ross, S.A.; Cheah, L. Uncertainty Quantification in Life Cycle Assessments: Interindividual Variability and Sensitivity Analysis in LCA of Air-conditioning Systems. J. Ind. Ecol. 2017, 21, 1103-1114. [CrossRef]

53. Shimako, A.H.; Tiruta-Barna, L.; de Faria, A.B.B.; Ahmadi, A.; Spérandio, M. Sensitivity Analysis of Temporal Parameters in a Dynamic LCA Framework. Sci. Total Environ. 2018, 624, 1250-1262. [CrossRef] [PubMed]

54. Redden, R.; Crawford, R.H. Valuing the Environmental Performance of Historic Buildings. Australas. J. Environ. Manag. 2020, 1-13. [CrossRef]

55. Favi, C.; Di Giuseppe, E.; D’Orazio, M.; Rossi, M.; Germani, M. Building Retrofit Measures and Design: A Probabilistic Approach for LCA. Sustainability 2018, 10, 3655. [CrossRef]

56. Yildırım, E. (Ed.) Action Plan: Cultural Heritage and Localizing the UN Sustainable Development Goals (SDGs); ICOMOS: Charentonle-Pont, France, 2017.

57. Hollberg, A.; Kaushal, D.; Basic, S.; Galimshina, A.; Habert, G. A Data-driven Parametric Tool for Under-specified LCA in the Design Phase. IOP Conf. Ser. Earth Environ. Sci. 2020, 588, 052018. [CrossRef] 
58. Omer, M.A.; Noguchi, T. A Conceptual Framework for Understanding the Contribution of Building Materials in the Achievement of Sustainable Development Goals (SDGs). Sustain. Cities Soc. 2020, 52, 101869. [CrossRef]

59. Wen, B.; Musa, S.N.; Onn, C.C.; Ramesh, S.; Liang, L.; Wang, W.; Ma, K. The Role and Contribution of Green Buildings on Sustainable Development Goals. Build. Environ. 2020, 185, 107091. [CrossRef]

60. Japanese Ministry of Internal Affairs and Communications (JMIAC) Japanese Ministry of Internal Affairs and Communications 2021. Available online: https:/ / www.soumu.go.jp/english/ (accessed on 15 March 2021).

61. Central Research Institute of Electric Power Industry (CRIEPI) Central Research Institute of Electric Power Industry. Available online: https: / criepi.denken.or.jp/en/index.html (accessed on 15 March 2021).

62. Method of Calculation and Evaluation Based on 2013 Energy Efficiency Laws and Commentary on it; Institute for Building Environment and Energy Conservation (IBEC); Commercial Printer: Tokyo, Japan, 2014.

63. Building Research Institute (BRI) Programme for Calculating Primary Energy Consumption in House Ver 2.8.1. Available online: https:/ / house.app.lowenergy.jp (accessed on 15 March 2021).

64. Kamatani, N.; Komatsu, Y. Study of the Life Span of Houses in Japan; 2011 Building Production System; Building Production Practice Report; Waseda University: Tokyo, Japan, 2011.

65. Promotion of Cultures and Conservation of Cultural Heritages; Japanese Agency for Cultural Affairs (JACA): Tokyo, Japan, 1999. Available online: https://www.bunka.go.jp/tokei_hakusho_shuppan/hakusho_nenjihokokusho/archive/pdf/r1402577_26.pdf (accessed on 15 March 2021).

66. Japan Meteorological Agency. 2021. Available online: http://www.jma.go.jp/jma/indexe.html (accessed on 15 March 2021).

67. The Japanese Association for Conservation of Architectural Monuments (JACAM); Sanayama Residence Restoration Report; Sanayama Residence Restoration Committee: Saku, Japan, 1977.

68. The Japanese Association for Conservation of Architectural Monuments (JACAM); Sonehara Residence Restoration Report; Sonehara Residence Restoration Committee: Azumino, Japan, 1977.

69. JACA Cultural Heritage. Available online: https:/ / bunka.nii.ac.jp (accessed on 15 March 2021).

70. Ota, H. Study of the History of Japanese House; Iwanami Shoten: Tokyo, Japan, 1984.

71. Morse, E.S. Japanese Homes and Their Surroundings; Harper: New York, NY, USA, 1889.

72. Nishi, K.; Hozumi, K. What is Japanese Architecture? (Horton H Trans.); Kodansha International: Tokyo, Japan, 1985.

73. Nagano Prefecture Culture and Art Information Dissemination Site. Cultural Nagano. Available online: https://www.culture. nagano.jp/en/ (accessed on 15 March 2021).

74. JMIAC (2021). Available online: https:/ / elaws.e-gov.go.jp/document?lawid=325AC1000000214 (accessed on 15 March 2021).

75. Uchida, T.; Yoshino, H. Study on Energy Consumptions and Indoor Thermal Environments in Japanese Traditional Houses Before and After the Insulation Retrofits, presented at AIJ Tohoku Branch Reporting Conference, Sendai City, Miyagi, Japan. AIJ Tohoku Branch Reports. Archit. Plan. 2010, 73, 17-20.

76. Kamakura, H.; Ichikawa, R.; Kawata, K.; Tajima, M. Investigation of Energy Retrofit for an Old House Part1. Outline of Energy Retrofit Technique and Evaluation of Energy Consumption, Presented at AIJ Shikoku Branch Reporting Conference, Kami city, Japan. AIJ Shikoku Branch Rep. 2017, 17, 37-38.

77. Katsuchi, Y.; Takamaura, H. LCA for a Well-Insulated and Airtight House for Two-Generation Family in Whole House with Continuous Heating and Cooling-Part 1: Comparison of LCCO2 Levels in One House in Terms of Insulation Specifications. J. Life Cycle Assess. Japan 2019, 16, 106-129.

78. Ozaki, R.; Lewis, J.R. Boundaries and the Meaning of Social Space: A Study of Japanese House Plans. Environ. Plan. D Soc. Space 2006, 24, 91-104. [CrossRef]

79. Stehn, L.; Bergström, M. Integrated Design and Production of Multi-storey Timber Frame Houses-Production Effects Caused by Customer-oriented Design. Int. J. Prod. Econ. 2002, 77, 259-269. [CrossRef]

80. Genjo, K.; Tanabe, S.; Matsumoto, S.; Hasegawa, K.; Yoshino, H. Relationship between Possession of Electric Appliances and Electricity for Lighting and Others in Japanese Households. Energy Build. 2005, 37, 259-272. [CrossRef]

81. Yoshida, F.; Yoshida, H. E-waste Management in Japan: A Focus on Appliance Recycling. In Advanced Materials Research; Trans Tech Publications Ltd: Bäch, Switzerland, 2014; Volume 878, pp. 420-423.

82. IBEC Commentary on Energy Efficiency Law for Houses; Commercial Printer: Tokyo, Japan, 2002.

83. Li, Y.; Gao, W.; Zhang, X.; Ruan, Y.; Ushifusa, Y.; Hiroatsu, F. Techno-economic Performance Analysis of Zero Energy House Applications with Home Energy Management System in Japan. Energy Build. 2020, 214, 109862. [CrossRef]

84. Dilshad, S.; Kalair, A.R.; Khan, N. Review of Carbon Dioxide $\left(\mathrm{CO}_{2}\right)$ Based Heating and Cooling Technologies: Past, Present, and Future Outlook. Int. J. Energy Res. 2020, 44, 1408-1463. [CrossRef] 